\title{
Current state of knowledge regarding the world's wetlands and their future under global climate change: a synthesis
}

\author{
Wolfgang J. Junk $\cdot$ Shuqing An $\cdot$ C. M. Finlayson • \\ Brij Gopal · Jan Květ $\cdot$ Stephen A. Mitchell • \\ William J. Mitsch • Richard D. Robarts
}

Received: 21 February 2012/ Accepted: 24 September 2012/Published online: 30 October 2012

(C) Springer Basel 2012

\begin{abstract}
Wetlands cover at least $6 \%$ of the Earth's surface. They play a key role in hydrological and biogeochemical cycles, harbour a large part of the world's biodiversity, and provide multiple services to humankind. However, pressure in the form of land reclamation, intense resource exploitation, changes in hydrology, and pollution threaten wetlands on all continents. Depending on the region, 30-90\% of the world's wetlands have already been destroyed or strongly modified in many countries with no sign of abatement. Climate change scenarios predict additional stresses on wetlands, mainly because of changes in
\end{abstract}

W. J. Junk (ه)

National Institute for Science and Technology in Wetlands (INCT-INAU), Federal University of Mato Grosso (UFMT), Av. Fernando Corrêa da Costa 2367, Bairro Boa Esperança, Cuiabá MT, Brazil

e-mail: wjj@evolbio.mpg.de

\section{S. An}

The Institute of Wetland Ecology, The State Key Laboratory of Pollution Control and Resource Reuse,

School of Life Science, Nanjing University,

210093 Nanjing, China

e-mail: anshq@nju.edu.cn

\section{M. Finlayson}

Institute for Land, Water and Society, Charles Sturt University, PO Box 789, Albury, NSW 2640, Australia

e-mail: mfinlayson@csu.edu.au

\section{B. Gopal}

Centre for Inland Waters in South Asia, National Institute of Ecology, 41 B Shiv Shakti Nagar, 302017 Jaipur, India e-mail: brij44@gmail.com

J. Květ

Faculty of Science, University of South Bohemia, Branišovská 31, 37005 České Budějovice, Czech Republic e-mail: Jan.Kvet@seznam.cz hydrology, temperature increases, and a rise in sea level. Yet, intact wetlands play a key role as buffers in the hydrological cycle and as sinks for organic carbon, counteracting the effects of the increase in atmospheric $\mathrm{CO}_{2}$. Eight chapters comprising this volume of Aquatic Sciences analyze the current ecological situation and the use of the wetlands in major regions of the world in the context of global climate change. This final chapter provides a synthesis of the findings and recommendations for the sustainable use and protection of these important ecosystems.

\section{J. Květ}

Institute of Systems Biology and Ecology,

Academy of Sciences of the Czech Republic,

Dukelská 145, 37901 Třeboň,

Czech Republic

\section{S. A. Mitchell}

Water Research Commission, Private Bag X03,

Gezina 0031, Pretoria, South Africa

e-mail: smitch2503@gmail.com

W. J. Mitsch

W. H. Schiermeier Olentangy River Wetland Research Park, The Ohio State University, 352 W. Dodridge Street,

43202 Columbus, Ohio, USA

e-mail: mitsch.1@osu.edu

R. D. Robarts

UNEP GEMS/WATER Programme,

c/o NWRI, 11 Innovation Blvd,

Saskatoon S7N 3H5, Canada

e-mail: Richard.Robarts@EC.GC.CA 
Keywords Wetlands · Distribution · Threats . Management · Climate change

\section{Introduction}

Although wetlands cover only about $6 \%$ of the earth's surface, they play a key role in biogeochemical cycles, are sources or sinks for carbon, are important buffers in the landscape's hydrology, and harbour a large part of the earth's biodiversity, including many endemic species. They provide many services for humans, such as food, water, recreation and space for living; all large tropical and subtropical wetlands still harbour traditional societies which have sustainably managed these systems often for centuries or even millennia.

Wetlands are often considered as wastelands, which should be transformed to "useful" systems, e.g., by traditional agricultural, forestry, husbandry and aquaculture, or for the construction of houses, and infrastructure. Wetland destruction is advanced in densely populated regions, such as Western Europe and parts of China, or in countries with shortages of water, such as Australia, and also in countries with powerful agro-industries, such as the USA. However, a global value for ecosystem goods, services, biodiversity, and cultural considerations of US\$ 6,579 $\times 10^{9}$ year $^{-1}$ has been estimated for all inland waters and wetlands in comparison to US $\$ 5,740 \times 10^{9}$ year $^{-1}$ for all other nonmarine ecosystems combined. The average values per unit area of rivers (US\$ 8,498 $\mathrm{ha}^{-1}$ year $^{-1}$ ) and wetlands (US\$ $14,785 \mathrm{ha}^{-1}$ year $^{-1}$ ) are higher than those of the most valuable terrestrial ecosystems, such as forests (US\$ $969 \mathrm{ha}^{-1}$ year $^{-1}$ ) and grasslands (US\$ $232 \mathrm{ha}^{-1}$ year $^{-1}$ ) (Costanza et al. 1997). The numbers of this estimate have been challenged, especially in relation to the accuracy of the scaling-out that was done, but there is still no doubt about the ecological and socio-economic importance of intact wetland areas (MEA 2005).

The predicted changes in global climate will, among other impacts, increase temperature, modify the precipitation regime, raise the sea level and increase extreme climate events. All these changes will have a large impact on wetlands. But wetlands are not considered adequately in many climate change scenarios. For instance, predictions about the future of the Amazon rain forest do not consider that $30 \%$ of the Amazon basin is composed of wetlands (Junk et al. 2011).

In response to this situation, we have assembled in this volume of Aquatic Sciences an overview of the available information on wetlands from around the world. We summarize this information in this synthesis chapter and provide a general global view on wetlands and their role in a changing world. Specific literature citations are given in the chapters by Mitchell (2012) for Africa, An et al. (2012) for East Asia and High Asia, Čížková et al. (2012) for Europe, Finlayson et al. (2012) for Australia, Gopal (2012) for tropical Asia, Junk (2012) for South America, Mitsch and Hernandez (2012) for North an Central America, and Robarts et al. (2012) for Russia.

\section{Wetland extent and classifications}

The current distribution and extent of wetlands no longer coincides closely with that which previously existed; the conversion and loss of wetlands has seen major changes in the area and ecological condition of many wetlands. Huge areas of wetlands have been destroyed in most countries. On the other hand, wetland restoration and man-made wetlands are becoming increasingly important. In the USA, during recent years, wetland restoration has increased the total area of wetlands. In China, $47 \%$ of the wetlands are human-made (rice paddy plantations and fish ponds). A similar situation is found in many tropical and subtropical SE Asian countries. But wetland destruction continues in most parts of the world, sometimes at an increasing rate, because of wetland-unfriendly land-use planning. However, the exact data about losses are not widely available.

The extent of wetlands is not known for several major regions, e.g., South America, Africa and Russia, because detailed inventories do not exist, and the definition of wetlands is not uniform. Small riparian wetlands along low order streams, as well as small depression or temporary wetlands, are often not considered, but may add up to large areas. For example, in the Amazon basin, these areas may cover up to 1 million $\mathrm{km}^{2}$. Table 1 indicates the order of magnitude of total wetland area in the regions described in this volume.

North and Central America cover an area of about $24.9 \mathrm{~km}^{2}$ and has a population of 529 million inhabitants (USA 9.83 million $\mathrm{km}^{2}, 308$ million inhabitants, Canada 9.98 million $\mathrm{km}^{2} 31.6$ million inhabitants, Mexico 1.97 million $\mathrm{km}^{2}, 110$ million inhabitants). Large parts of Alaska and Canada have a very low human population density and are covered by boreal peatlands and permafrost soils with a high storage capacity for organic carbon. The central drier part contains the prairie potholes and large river floodplains of the Mississippi, Missouri and Ohio Rivers, which join to form a large subtropical delta in the Gulf of Mexico. Several large wetlands have traditionally elicited specific attention based on their size, their biodiversity, their landscape beauty, and/or their potential for agriculture, such as the Everglades in Florida. The wetland area in Mexico and Central America is much smaller than 
Table 1 Total wetland area, area of artificial wetlands, and percentage wetland area of the respective land area, where this is known

? not known

${ }^{a}$ Conservative estimate without Algeria, Egypt, Libya, Mauritania, Morocco, Tunisia and Western Sahara, and without wetlands along low order rivers and coastal wetlands

\begin{tabular}{lccll}
\hline Region & Land area $\left(\mathrm{km}^{2}\right)$ & Wetlands (tot.) $\left(\mathrm{km}^{2}\right)$ & Wetlands (art.) $\left(\mathrm{km}^{2}\right)$ & Wetland $(\%)$ \\
\hline N. \& C. America & $24,900,000$ & $2,490,000$ & $?$ & 10 \\
Europe & $10,000,000$ & 500,000 & $?$ & 5 \\
Russia & $17,075,400$ & $>1,800,000$ & $?$ & $>10$ \\
China & $9,600,000$ & 684,900 & 322,900 & 7 \\
South America & $17,850,000$ & $>3,000,000$ & $?$ & $>20$ \\
Africa & $30,065,000$ & $2,129,285$ & $?$ & 7 \\
Sub-Saharan A. & $23,003,885$ & $2,072,775$ & $?$ & 9 \\
Tropical Asia & $14,536,000$ & 686,570 & $?$ & 2.8 \\
Australia & $7,692,024$ & 230,077 & 6,657 & 3 \\
\hline
\end{tabular}

in the USA and Canada, with most found at or near the coastlines.

Europe covers an area of 10.5 million $\mathrm{km}^{2}$ and harbours 733 million inhabitants. The population density is very high in some West-European countries, e.g., in The Netherlands (380 persons $\mathrm{km}^{-2}$ ) and in Germany (231 persons $\mathrm{km}^{-2}$ ). This high population density has created heavy pressure on many wetlands. The abundant peat bogs in Western Europe have been mined and freshwater marshes have been reclaimed as valuable arable land. Coastal marshes and parts of the periodically flooded Wadden Sea in the North Sea were converted to polders and used for pastures. Flood protection has eliminated most large river floodplains; along the Rhine River and on the upper Danube River only small remnants of the formerly extended floodplains are left and are now under protection. Major floodplains exist on the lower Danube and in the Danube Delta and along Russian rivers. In the European part of Russia large peat bogs still exist.

Russia covers an area of $17,075,400 \mathrm{~km}^{2}$ and harbours 143 million people. Large areas support a population density of $<2$ persons $\mathrm{km}^{-2}$ and large near-pristine wetlands. About two-thirds of Russia's land area is covered by flat lands (lowlands, plains and low hills with average heights of not greater than $600 \mathrm{~m}$ ), which contributes to the development of conditions favouring wetland formation. Wetlands cover $>1.810^{6} \mathrm{~km}^{2}$ and are most prevalent in the north. Some wetlands are expanding, such as in the West Siberian Plains. Most common are peat bogs that cover 1.6-1.8 million $\mathrm{km}^{2}$ corresponding to $1 / 3$ of the worlds peat lands. In the Russian Arctic $0.75 \times 10^{6} \mathrm{~km}^{2}$ of permafrost wetlands exist. The large Russian rivers are accompanied by extended river floodplains and large deltas.

China covers an area of 9.6 million $\mathrm{km}^{2}$ and harbours a population of 1.34 billion people. Large areas of the country, however, have a very low population density because of an adverse climate, e.g., steppes and deserts and the Himalayan mountains. For millennia, Chinese wetlands have been intensively managed by the local population for rice and fish culture. Near natural wetlands cover an area of about $362,000 \mathrm{~km}^{2}$ and correspond to $53 \%$ of the total wetland area. Human pressure on wetlands is rising, mainly in the coastal regions. The extended river floodplains along the large Chinese rivers are heavily affected by reservoir construction.

South America covers an area of 17.8 million $\mathrm{km}^{2}$ and contains a population of 381 million inhabitants. But this population is concentrated along the coastline and in some cities along the large rivers. Large areas of South America have a human population of $<2$ persons $\mathrm{km}^{-2}$ and many near pristine wetlands. South America is a wet sub-continent. About one-third of its area is covered by tropical rainforest (biomes of Amazon Rain Forest and tropical and subtropical Atlantic Forest). It is dominated by large river systems. The Amazon, Orinoco, and Paraná/Paraguay Rivers have the highest, third, and tenth highest discharge among the largest rivers in the world and are accompanied by extended fringing floodplains. Flat interfluvial areas are periodically flooded during the rainy season and form extended wetlands. Therefore, most South American wetlands belong to the floodplain category with a pulsing water-level and pronounced dry and wet periods. Permanently waterlogged areas occur mostly under boreal climatic conditions in Patagonia and in the Andean high plains. Mangroves cover $45,400 \mathrm{~km}^{2}$ mostly along the Atlantic coast, corresponding to $27 \%$ of the world's total mangrove area (Lacerda 2002).

Africa covers an area of 30.3 million $\mathrm{km}^{2}$ and harbours a population of about 944 million people, Large areas, however, have a very low population density because of adverse climatic conditions. The central part around the equator is covered by the tropical rain forest in the Zaire River basin. Adjacent to the North and South savannas, deserts prevail including the Sahara Desert, the largest desert on the globe. Several rivers, such as the Nile, Zaire, Niger, Zambesi, and Okavango with fringing floodplains and internal deltas, dominate the scenario of African wetlands. Most of them have a pronounced wet and dry period and are subject to a flood pulse. Mangroves cover 
$32,600 \mathrm{~km}^{2}$, comprising $19 \%$ of the world's total. Most African wetlands have been colonized by humans for millennia and make an important contribution to the livelihoods of the local populations. Increasing conflicts for water and land threaten African wetlands.

Tropical and subtropical South-East Asia cover an area of about 24.5 million $\mathrm{km}^{2}$ and has approximately 2.8 billion inhabitants. Most areas are densely populated, e.g., India with a population of 1.21 billion people and a density of 350 persons $\mathrm{km}^{-2}$. The monsoonal climate favours the occurrence of intermittent wetlands and river floodplains. But a large variety of local climatic conditions leads to a large variety in wetland types and total wetland extent. The large SE-Asian rivers, such as the Mekong, Ganges, Brahmaputra, Irrawaddy, Indus, Euphrates and Tigris are accompanied by extended fringing floodplains and form large deltas. Tonle Sap is connected to the Mekong River and provides the highest catch of an inland fishery worldwide. High population density and millennia of wetland cultivation have dramatically reduced the size of natural wetlands as a result of conversion to artificial wetlands, mainly for rice paddy plantations, fish ponds and small reservoirs. With $75,100 \mathrm{~km}^{2}$, tropical and subtropical South-East Asia contains about $44 \%$ of the world's mangrove area. Of special interest are the peat swamp forests in Indonesia, which represent the most important tropical wetlands with a high carbon store and which are under severe human pressure.

Australia covers about 7.69 million $\mathrm{km}^{2}$ and has a population of 22.6 million persons. Large areas have a population density $<2$ persons $\mathrm{km}^{2}$. It is a very dry continent, with a low percentage of wetland area. Many wetlands are intermittent, often with multiannual dry periods because of variable and unpredictable rainfall events. Exceptions include the mangroves that cover about $17,200 \mathrm{~km}^{2}$, corresponding to $10 \%$ of the global total. Extensive coastal floodplain wetlands occur along the tropical, northern and north-eastern coasts, including those within Kakadu National Park. Despite a very low population density, the continent struggles with water shortages. Water abstraction strongly affects river discharge and connected floodplains, e.g., in the Murray-Darling Basin. In response there has been a large investment in water-useefficiencies and environmental flow allocations. The area of wetland as derived from official mapping products comprises $3 \%$ of the landmass, although there are also significant areas of marine wetlands not included in this figure.

\section{Wetland classification}

Countries with a well developed wetland policy, such as the USA, Europe and Australia have wetland classifications corresponding to legal or jurisdictional requirements. Others, such as Russia, apply the wetland classification scheme of the USA with some modifications to take into account specific features of their wetlands. For some major world regions general classification systems exist, e.g., for South Asia. Many countries without a national wetland classification have separate habitat classifications for specific wetlands or wetland types, such as Argentina and Brazil, but they have little impact on local policy. For the purposes of supporting legislation dealing with the management and protection of wetlands, politicians and planners would benefit from a convergence in approaches and the adoption of a unified classification.

\section{State of knowledge, research efforts and research infrastructure}

Wetland research and management during the past few decades has become increasingly important, however, to different ways around the world. At the global level, the International Union for the Conservation of Nature and Natural Resources (IUCN), the Ramsar Convention, and Wetlands International have dealt extensively with different aspects of wetland protection. Since 1980, the Wetland Working Group of the International Association of Ecology (INTECOL) has held an international conference somewhere in the world every 4 years. The journals Wetlands and Wetlands Ecology and Management deal specifically with wetlands, but there are many other scientific journals that also publish articles on wetland-related topics. Nongovernmental agencies, such as The Nature Conservancy and Worldwide Fund for Nature also deal with wetlandrelated problems.

At the regional level, the picture is heterogeneous. The status of knowledge about wetlands is relatively high in Europe, North America and Australia, partly because past large-scale wetland destruction has led to increasing awareness by the public about the value of wetlands. An increasing amount of data is becoming available about the wetlands of China and most countries of tropical SouthEast Asia, Africa and Central America, as high human pressure on wetlands and an increasing need for water requires political actions by national governments. In South America, some key wetlands, such as the Pantanal, parts of the floodplains of the Paraná, Magdalena, Orinoco and Amazon Rivers, and some boreal swamps of Patagonia are reasonably well known, while others are very poorly studied. Least known are the wetlands of Russia.

In North America, many institutions deal with wetlands. The Canadian Rivers Institute at the University of New Brunswick, Wetland and Waterfowl Research (IWWR) the scientific research arm of Ducks Unlimited, and Wetlands Research Center, University of Waterloo, should be mentioned among others. Several research centers in the United 
States concentrate on wetlands, such as the Sapelo Island Marine Institute in Georgia, the School of Coast and Environment at Louisiana State University, the H.T. Odum Center for Wetlands at the University of Florida, the Duke Wetland Center at Duke University, and the Wilma H. Schiermeier Oletangy River Wetland Research Park (ORWRP) at Ohio State University. The U.S. Fish and Wildlife Service, U.S. Environmental Protection Agency, the U.S. Army Corps of Engineers, U.S. Environmental Protection Agency, the U.S. EPA, especially through its Office of Wetlands, Oceans, and Watersheds (OWOW), and the Natural Resources Conservation Service are the primary wetland management agencies in the United States (Mitsch and Gosselink 2007). The Association of State Wetland Managers and the Society of Wetland Scientists (SWS) disseminate information on wetlands, particularly in North America, with SWS having recently established chapters in several other regions. The INTECOL Wetland Conference has been held three times in North America: Columbus, Ohio, USA (1992), Quebec City, Quebec, Canada (2000), and Orlando, Florida, USA (2012).

In most European countries, wetland research centers undertaking basic and applied research projects are found. A number of universities offer courses on wetland ecology and management and the state of knowledge about wetlands is rather good. Research concentrates mostly on wetland management, protection and restoration. In 2004, the Society of Wetland Scientists established a European chapter whose annual meetings are becoming a representative forum for European wetland scientists (Zak et al. 2011). The Wetlands Working Group of INTECOL has a broad base of collaborating wetland scientists who gather at International Conferences on Wetlands every 4 years with three out of eight of these conferences held so far at the European wetland research centers at Třebon (Czechoslovakia), Rennes (France) and Utrecht (The Netherlands).

In Russia, wetlands were recognized only in 1989 as a separate type of ecosystem. Knowledge on wetlands and appreciation of their value has steadily increased during the last decade, but is dispersed in many different reports and journals and is far from being satisfactory. Currently in Russia there is no research team or group that focuses primarily on wetlands as a specific ecosystem type. There is no equivalent in Russia of the Society of Wetland Scientists in North America. The influence of scientists on Russian policy is small.

In China, the central government started the national research on wetlands in 1997 under help of UNDP, GEF and WB, and published the first guideline book of China's national wetland conservation action plan. The first national inventory of wetlands was undertaken during 1997 and 2003, and all information about China's wetlands was taken from this inventory. The second inventory with more detailed information begun in 2010 and will be completed in 2015. There are a few institutes focusing on wetland research, such as Nanjing University, Nanjing Institute of Geography and Limnology of Chinese Academy of Science, East China Normal University, Northeast Institute of Geography and Agricultural Resource of Chinas Academy of Science. The number of wetland scientists in China is too small to meet the requirements of national wetland management.

Most South-American countries have wetland research activities going on in various universities and research institutions. Research infrastructure is improving but insufficient for a modern research and development policy of the countries. The different research groups are not interlinked and their political influence is small. The INTECOL-wetland conference, held in 2007 in Cuiabá, Brazil, has called attention to South America and has given a positive signal to the research community.

In Africa, international NGOs and various donor agencies have been active in researching the role of wetlands in the livelihoods of the local populations and this has contributed to the substantial knowledge of certain of the larger and more prominent systems. Uganda leads the way in incorporating this knowledge into policy and management in a way that aims to provide sustainable wetland management while providing sustainable livelihoods for people living adjacent to the wetlands. In southern and eastern Africa there has been ongoing research into the implementation of environmental water requirements of rivers, wetlands and estuaries based on the understanding that without sufficient water, these systems will be unable to provide the benefits required of them by the people who use these benefits.

In tropical and sub-tropical Asia, research on wetlands has progressed well though the countries differ considerably among themselves. Inventorisation and management issues have received considerable attention. Most of the research is lead by the universities though several research institutes such as the Wildlife Institute of India, Salim Ali Centre of Ornithology and Natural History and NGOs like the Bombay Natural History Society, WWF, IUCN and Wetlands International with their offices in several countries of the region contribute extensively to the knowledge of wetlands. Much interest in recent years has emerged in using the tools of ecological economics for valuation and management of wetlands.

In Australia, the status and knowledge of wetlands has increased in recent years with greater understanding of their distribution and extent, biota and ecological condition. Research capacity is spread across many separately operating units, although there have been significant efforts to establish collaborative research efforts. A number of 
research institutions deal specifically with rivers and wetlands, namely the Australian Rivers Institute at Griffith University, the Australian Wetlands and Rivers Centre at the University of New South Wales, the Murray-Darling Freshwater Research Centre at Latrobe University, and the Australian Centre for Tropical Freshwater Research at James Cook University. Many universities support wetland and river research through wider and more inter-disciplinary environmental research centres including the Institute for Applied Ecology at Canberra University, the Institute for Land, Water and Society at Charles Sturt University, and the Centre for Environmental Management at Ballarat University.

Several research programs have dealt with wetlands and aquatic resources, such as eWATER, The Queensland Wetlands Program, Land and Water Australia, The National Land and Water Resources Audit. Recent research has in particular focussed on wetlands in the MurrayDarling Basin by the River Environmental Restoration Program coordinated by the New South Wales Department of Environment, Climate Change and Water and by the Living Murray Initiative (Pittock \& Finlayson 2011). A further substantial wetland program is being undertaken by the CSIRO Water for a Healthy Country. Further national wetland research and assessment efforts include the National Aerial Waterbird Surveys, the National River Health Assessment, the Tropical Rivers Inventory and Assessment Project, the Tropical Rivers and Coastal Knowledge Program, and many others.

\section{Wetlands use by traditional and modern human societies}

Humans have largely had an antagonistic relationship with wetlands because of difficult access, insect nuisance, and water-born diseases, In Europe and Russia, they often served as refuge for persecuted people and criminals, in other parts of the world as refuge for ethnic minorities, such as the Totora swamps at Titicaca Lake for the Aymaras, the Schatt al-Arab at the confluence of the Euphrates and Tigris for the "Marsh Arabs", and the Everglades for the Seminoles. The importance of wetlands for the colonization by humans depended mainly on two factors: the predictability of the hydrological regime and the productivity of the wetland system.

In temperate regions, the flood pulse of large riverfloodplains was less predictable and floods often occurred during the growing season, putting crops and domestic animals at risk. This hindered the development of floodadapted management strategies and favored flood protection by diking, when technical capacities became available. In Germany, the engineer Tulla started straightening of the
Rhine River channel at the beginning of the 19th century. Today, only a few square kilometers of near-natural floodplain areas are left.

Northern peat bogs have a rather stable water level, but are of very low nutrient status and productive capacity. In the past, they were used for peat mining and later drained for pasture and crop land plantation. Coastal wetlands were poldered for pastures and crop-land. For instance, since the 16th century, parts of the Wadden Sea in northern Europe were poldered, and the last polder in Germany was completed in 1954. Now, the remaining Wadden Sea is partly protected and poldering has been stopped.

In the tropics and subtropics, large river floodplains and rainwater-fed wetlands show a predictable flood pulse (Junk et al. 1989). This favors the development of floodadapted management strategies. Most tropical rivers transport fertile water and sediments to their floodplains. Tropical and sub-tropical climates allow agriculture and animal ranching during the low water period, and a fishery throughout the year. Very advanced civilizations developed thousands of years ago in the floodplains along the rivers Nile, Ganges/Brahmaputra and Euphrates and Tigris. The highly productive fishery of the Mekong River and Tonle Sap provided protein to the large population that constructed the famous temples of Angkor Wat in Cambodia, from the tenth century onward. The density of preColumbian population in the nutrient-rich Amazon River floodplain was several times higher than that in the surrounding nutrient-poor upland, but also in the nutrient-poor black water river floodplain of the Negro River. Most of the large, South-American rainwater-fed floodplains were also colonized in pre-Columbian times by indigenous populations. Fisheries, hunting and intensive agriculture compensated for a lower productivity level of water and sediments. All large South American, African and SouthEast Asian floodplains are still colonized today by local people, who manage the systems in a traditional way (Junk 2002; Gopal et al. 2008).

High production makes wetlands important for flood recession agriculture as well as for grazing of livestock, pursuits that are practiced in wetlands throughout Africa. An example of high productivity is the Sudd one of three very large wetlands in the Sahel region. The river-flooded grassland has a higher productivity compared to the grassland seasonally flooded by rainfall, and changes to the area flooded by the river will have an impact on the quality of grazing. This will translate to the number of cattle which can be supported, but to fish production as well. In addition, wetlands provide other necessities for subsistence farmers such as handcrafts and building materials, plant (e.g., medicinal) and animal harvesting.

Seasonally flooded wetlands provide rich fisheries and for the people living on wetlands the fishery is either the 
sole source of, or an important contribution, to their livelihoods (Welcomme 1979). Béné (2005) estimated that several hundreds of thousands of households in Africa depend on fisheries and related activities and that between 450,000 and 500,000 people are directly involved in full time activities related to inland fisheries in West and Central Africa with a potential value of approximately US $\$ 750$ million annually. Bayley and Petrere (1989) estimated fish production of the Amazon River floodplain to be about 900,000 $\mathrm{t} \mathrm{year}^{-1}$, which is not yet fully exploited.

Emerton (2005) describes freshwater ecosystems as amongst Africa's most undervalued resources and with no apparent economic benefit to conserving wetlands. As a result, the services they offer continue to be degraded either from lack of understanding or for perceived short term economic gain. The methods for valuing wetlands, however, have developed to a point where they better assess the importance of the goods and services that wetlands deliver, many of which are non-market or subsistence values. The informal sector is well developed in Africa and, as a result, much of the value derived from wetlands is not measured in the formal economy. This is particularly true for the rural poor who depend on these services for their livelihoods and use the resources at a household level. Wetlands are particularly important to these people in times of crop failure or drought. In most of the tropical and subtropical Asian countries, wetlands have been traditionally valued very highly, because rice and fish are staple food, and floodplains have been major grazing grounds besides providing valuable resources. In most of the region, several local communities have lived in wetlands for their subsistence.

\section{Threats}

Land reclamation for agriculture

Wetland destruction around the world has often been caused by land reclamation and drainage because of high human population density. This has been documented in many places around the world. Eighty to ninety percent of the wetlands in Southern Ontario, Canada's most populated region have been destroyed. 60-90\% of the European wetlands disappeared during the last century. Rapidly increasing human population in Africa and many Asian countries requires an increase of food production that is often reached by the reclamation of intact wetland areas instead of the rational use of available agricultural areas. Over half the wetlands in semi-arid South Africa have been destroyed through commercial agriculture and mining practices as well as urban development. In some tropical and subtropical countries, such as Brazil and Indonesia, export-oriented agro-industries are increasingly destroying wetlands. In various tropical countries, up to $75 \%$ of the mangroves have been lost and similarly, up to $50 \%$ of southeast Asian peatswamps have been either cleared or converted to oil palm plantations. During the past 50 years, China has lost $22 \%$ of its natural wetlands; more importantly, this includes $51 \%$ of coastal wetlands.

It would be overly simplified, however, to relate wetland destruction only to high population density. Pressure on wetlands to provide arable land differs in different major world regions and has increased or decreased throughout historical times. Large wetlands in the USA, such as the Great Dismal Swamp on the Atlantic Coastal Plain, The Great Kankakee Marsh of north-western Indiana, and north-eastern Illinois, The Great Black Swamp in northwestern Ohio and major parts of the Everglades in Florida, have been drained for agricultural purposes. But, after a period of intense wetland reclamation, the US government now requires mitigation for any destroyed wetland area. Europe experienced large wetland destruction since the medieval era until the middle of the last century. In Russia, large-scale organized wetland drainage for agriculture began with Peter the Great in the late 17th century and early 18th century. Under the Soviet government there was an enforced policy to drain wetlands and reclaim the land mainly for farming a practice that was largely discontinued after the collapse of the USSR.

In many cases, modern-style, wetland-unfriendly management has a low economic benefit and severe negative social and cultural side-effects. In densely colonized southern Brazil, deforestation of steep slopes accelerates rainfall run-off and creates land-slides. River straightening and canalization, and large scale reclamation of wetlands for agriculture and civil construction increased flood peaks. During the rainy season in 2010/11, the state of Rio de Janeiro was heavily affected by land-slides and floods, which cost nearly 1,000 lives, and in 2011/12 the state of Minas Gerais suffered heavy floods, killing several people and turning-out tens of thousands from their homes. This does, however, not hinder the Brazilian government from changing the Forest Code that will facilitate and accelerate wetland destruction (Sousa et al. 2011).

The demands of international markets have led to further wetland degradation from increases in beef production in South America, food for domestic animals (soy beans) produced in South America, and the production of irrigated rice in Africa, and wetlands provide part of this increase in production. Water is considered a free resource that can be used for irrigation and domestic and industrial uses. In fact, it is a public good on which rivers, floodplains, wetlands and their biodiversity depend on, but little attention is given to this view. The conclusion reached by FAO (1997) for African wetlands is that the "economic value of the 
wetlands is very large, many times greater than that of all the irrigation schemes for which the inflowing rivers are dammed, diverted and their waters used'.

For cost-benefit analyses of irrigation projects in semiarid zones, considerations about the "virtual water content" of agricultural products may be important. $0.45-1.90 \mathrm{~m}^{3}$ of water are required for the production of $1 \mathrm{~kg}$ maize, for wheat it is $1.15-2 \mathrm{~m}^{3}$, for soybean it is $2.3-2.75 \mathrm{~m}^{3}$, for rice it is $1.4-3.6 \mathrm{~m}^{3}$, and for beef it is 13.5-20.7 $\mathrm{m}^{3}$ (Hoekstra 2003). A realistic price for water would make many large irrigation projects of local governments and of international agro-business consortia economically non-viable and favor wetlands and low impact traditional wetland use and management.

A recent world-wide increase in the demand for biofuels (e.g., alcohol, palm oil) has increased the pressure on wetlands in many tropical countries, e.g., in undisturbed savannah of the Brazilian Cerrado and the Argentinean Chaco, and the Indonesian swamp forests. Riparian and depression wetlands are destroyed or degraded by increased input of sediments and agrochemicals. In Western Europe, subsidies for the production of biogas have increased the demand on land for biomass production at the cost of other production systems, including ecologically valuable wet meadows.

The expansion of agriculture in natural dryland areas may affect wetlands far away. For instance, increased erosion in agricultural areas in the catchment of the Pantanal has increased the sediment load of the tributaries. The channel of the Taquari River was filled with sediments and the river broke through the natural levees and has modified the hydrology of an area of about $11,000 \mathrm{~km}^{2}$ inside the Pantanal, with dramatic consequences for the environment and the local ranchers.

\section{Reservoir and dike construction}

A major threat to wetlands is the construction of reservoirs, which store part of the annual surface run-off from the continents for irrigation, hydropower generation, flood control and water supply. The World Commission on Dams (2000) reports that there are over 45,000 large reservoirs (dam height $>15 \mathrm{~m}$ and/or reservoir volume $>3$ million $\mathrm{m}^{3}$ ). This number is steadily increasing. In South America, Brazil generates over $93 \%$ of its electricity from hydropower, Paraguay c. $100 \%$, Peru $74 \%$, Venezuela $73 \%$, Ecuador $68 \%$, Colombia $68 \%$ and Chile $57 \%$. In Africa, most large dams are built for irrigation and water supply but, nevertheless, hydropower contributes more than $80 \%$ of electricity production in 18 countries and over $50 \%$ in 25 countries. As of 2000, 2,000 MW of generating capacity was under construction in Africa. Hydropower contributes to more than $50 \%$ of the electricity supply in Fiji, New
Zealand, Papua New Guinea and New Caledonia (World Commission on Dams 2000). Apart from North America, Europe and Australia, reservoir construction will continue. These dams and many smaller ones change the discharge pattern and sediment load of rivers and interrupt longitudinal connectivity. They modify the ecological conditions in floodplains with far reaching negative impacts on their structures and functions including their biodiversity.

The situation is aggravated by dike construction along major rivers for flood protection. This measure interrupts lateral connectivity between rivers and their floodplains. All large rivers in Europe and North America are accompanied by dikes and the respective river floodplains are destroyed or heavily modified. In central and western Europe, only small remnants of the former extended river floodplains are left. The risk of floods may support the political penchant for constructing ecosystem unfriendly flood defenses, which threaten the hydrology of the few remaining river floodplains. The Netherlands and Germany have also transformed large parts of their coastal wetlands into pastures.

In South America, reservoir construction for flood protection, irrigation, water supply, and hydroelectric power generation has degraded the floodplains of the Magdalena River and the upper Paraná River. Reservoir construction is expected to increase across most of South America, Africa, China and tropical and sub-tropical Asia. Lack of water is driving reservoir construction at all large rivers of the Indian subcontinent with dramatic impact on their floodplains and deltas. Increasing water demand in the upper catchment of the Okavango River will affect the famous Okavango delta.

Biodiversity and the invasion of exotic species

Wetlands harbor a considerable portion of the biodiversity of a landscape (Gopal et al. 2000, 2001). For example, the Prairie Pothole Region (PPR) of North America supports $50-80 \%$ of the continent's duck population. Large wetlands also harbor permanently or periodically considerable numbers of species and sometimes large populations from surrounding terrestrial ecosystems. Only 104 of the 390 bird species, registered from the Pantanal in Brazil, are wetland specific or wetland dependent. The others are upland species, some of them endangered. The populations of large ungulates of African savannas depend in part on water and food provided by the wetlands during the dry season, such as the Okavango Delta. This gives wetlands a specific importance to the maintenance of biodiversity under global climate change.

But the number of exotic plant and animal species in wetlands is steadily rising, as well documented in literature. Introduction occurs by negligence or by deliberate 
release and is favored by the worldwide trade with plants and animals. Many exotic species become permanently established, often to the detriment of native ones. One of the most affected areas are the Everglades with 221 introduced plant species, 32 fish species, about 30 amphibian and reptile species, and 10 mammal species. Several species create serious environmental problems such as the Brazilian pepper (Schinus terebinthifolius), the Australian paper bark tree (Maleleuca quinquenervia), and the Asian tiger python (Python morulus). However, these deterrent examples do not hinder the introduction of exotic species to other wetlands by local people. For example, despite prohibition by law, the flood tolerant African grass Brachiaria humidicola was introduced in the Pantanal, and ranchers now distribute it across the entire area, because they believe that it may improve the quality of pastures. The predatory Amazonian peacock bass (Cichla ocellaris) was introduced in several South American inland waters to improve sport fishing activities with detrimental effects on the local fish fauna. Several bivalves were introduced to South America with ballast water by ships, such as Corbicula fluminea and C. largillierti in the 1970s and the Asian golden mussel (Limnoperna fortunei) in 1993. In 20 years, the golden mussel has spread over the entire Paraná/Paraguai River system excepting the headwaters (Mansur et al. 2012). Changes in global climate will stress the native flora and fauna and favor invasive species, including disease vectors.

\section{Management and protection}

At an international level, the Ramsar convention provides an important framework for wetland protection. In 2011, 160 contracting parties have signed the Ramsar Convention and have declared 1,950 sites as international important, covering a total area of $1,901,366.12 \mathrm{~km}^{2}$ (12 July 2011). About half of the protected area belongs to the regions (Table 2) being discussed here.

These numbers, however, strongly underestimate the total area of protected wetlands. All countries have many different kinds of protected area designations for specific wetlands which are not declared as Ramsar sites. Also, many other protected areas such as National Parks contain wetlands. Brazil, for instance, has declared about one million square kilometres as indigenous territories, mostly in the Amazon basin. About $20 \%$ of this area may be considered wetlands which are well protected, because most traditional indigenous land-use systems ensure a level low of environmental impact. There are considerable differences at the level of major world regions.

North America: After a period of heavy wetland destruction in North America from about the 1850s to the
Table 2 Number and area of Ramsar sites in major geographic regions (SOURCE: http://www.ramsar.org/cda/en/ramsar-documentslist/main/ramsar/1-31-218_4000_0__)

\begin{tabular}{lcr}
\hline Major area & Sites (nr.) & Area $\left(\mathrm{km}^{2}\right)$ \\
\hline North America & 185 & $227,002.84$ \\
Europe (except Russia) & 936 & $153,981.91$ \\
Russia & 35 & $103,237.67$ \\
China & 37 & $31,685.35$ \\
South America & 95 & $290,703.99$ \\
Africa (excluding islands) & 277 & $823,966.99$ \\
Tropical Asia & 163 & $97,476.30$ \\
Australia & 64 & $75,101.77$ \\
\hline
\end{tabular}

1970s, initiatives have been taken to effectively protect wetlands. Strong wetland protection regulations initiated in the mid-1970s and mid-1980s, based on the Clean Water Act, have had a dramatic effect and slowed the rate of loss. In one of the recent assessments of wetland trends in the US, wetland restoration and the creation of stormwater ponds exceeded the loss of natural wetlands and led to a slight increase in total wetland area. It remains controversial as to whether the created and restored wetlands are functionally equivalent to the natural wetlands that are lost to development (NRC 2001; Gardner et al. 2009).

Europe: At the international level, the member states of the European Union have signed international conventions aimed at nature protection with the Ramsar Convention being the primary basis for the conservation of the most valuable wetlands. There are 47 contracting parties to the Ramsar Convention in Europe, which have designated 898 European wetlands of international importance. These 898 sites represent about $50 \%$ of the total number of all Ramsar sites worldwide. However, these sites occupy only $14 \%$ of the area of all the world's Ramsar sites.

The European Commission promotes a long-term program, Life-Nature, which has supported the restoration of many coastal and inland wetlands during the last 15 years across Europe, and also in neighbouring countries. It is still operating, active and stimulating cooperation between managers, stakeholders, scientists and land owners. International and national legislation primarily aimed at improving the quality of surface waters (e.g., the Convention for the Protection of the Rhine (http://www.iksr.org), Convention on the International Commission for the Protection of the Elbe (http://www.ikse-mkol.org), the Danube River Protection Convention (http://www.icpdr.org) as well as various river and floodplain restoration projects have indirectly contributed to the conservation of existing wetlands.

Russia: The USSR has no specific wetland protection programs. But several wetlands are included in Russian 
National Parks that indirectly provide protection. Some important wetland areas are included in the Ramsar convention.

China: Wetland protection started only recently in China. Only in the early 1980s did the government establish the first natural wetland reserve. Since then, 460 reserves have been created, protecting $440,000 \mathrm{~km}^{2}$ of wetlands and related ecosystems. In recent years, several pilot projects aimed at wetland restoration were supported by the government.

South America: South American countries have no specific wetland management programs. In areas with a low population density and without agro-industrial activities wetlands are little impacted. All South American countries have protected large wetland areas by different types of reserves including large Ramsar sites.

Africa: In Africa, the vision and strategic framework of the New Partnership for Africa's Development (NEPAD) has four primary objectives: (1) to eradicate poverty, (2) to place African countries on a trajectory of sustainable growth and development, (3) to integrate Africa into the global economy and (4) to accelerate the empowerment of women. It is recognized that wetlands sustain livelihoods across large parts of the African continent, and so the aim expressed for wetland management by the NEPAD Action Plan for the Environment Initiative (2003) is that 'African countries and their people have healthy and productive wetlands and watersheds that can support fundamental human needs (clean water, appropriate sanitation, food security and economic development)'. The NEPAD document sets out a suite of targets against which progress towards achieving successful wetland conservation may be measured.

Within tropical and sub-tropical Asia, none of the countries has an exclusive national policy on wetland protection although such policies are being correctly discussed in Malaysia, Thailand and Bangladesh. Cambodia, China, Indonesia, Pakistan, Philippines and Vietnam have, however, National Wetland Action Plans. India has recently notified legal measures for the protection of Ramsar sites.

The Australian Federal Government has entered into various treaties and commitments to ensure the wise use and conservation of wetlands, in particular the Ramsar Convention on Wetlands and a number of bilateral treaties with countries in eastern Asia. The implementation of these treaties has depended to a large extent on leadership being provided by the Federal Government with uneven support by the provincial governments that largely have responsibility for land and water management. The Federal Government has significant powers under the Environment Protection and Biodiversity Conservation Act and the more recent Water Act, but it is arguable whether these are being used to the degree that is possible or necessary to secure the conservation and wise use of Australia's wetlands. A number of wetland policies were developed in the 1990s in particular with various commitments being made. It is increasingly being recognised that wetland restoration is needed in many river basins, with a small number of significant projects being implemented.

\section{The importance of wetlands for global climate and impacts of global climate change on wetlands}

\section{Paleoclimatic history}

Studies on the paleoclimate may provide information about the vulnerability of major world regions to expected climate changes and give hints to the consequences. During the last glacial period, large parts of the northern hemisphere were covered by ice. After the Last Glacial Maximum (LGM), about 18,000 years ago, global temperature increased worldwide. On a continental scale, the retreat of the glaciers led to a large scale rearrangement of ecosystems.

Most of today's waterbodies and wetlands in temperate and boreal regions of North America, Europe, and Russia developed after the LGM. The increase in temperature led to a shift of temperate and boreal species to higher latitudes and, in mountainous regions, to higher altitudes. This dislocation is expected to continue in the future with raising temperature. However, we oppose the prediction of Loarie et al. (2009), in which a general temperature driven ecosystem dislocation will happen, because the existence of many ecosystems does not depend on temperature. For instance, the occurrence of flooded grasslands, deserts, and mangroves is certainly not correlated only with temperature, but also with water availability. While the species composition may change, these and other tropical and subtropical ecosystems will be maintained at the same locality as long as the hydrological conditions are suitable.

China: There is no information available about paleoclimatic impacts on wetlands in China.

Paleoclimatic evidence in South America points to a drier and cooler climate during the LGM. With raising temperature, wetter and drier periods changed at a regional scale. In the 1970s, various authors postulated the fragmentation of the Amazon rain forest during glacial periods to explain the large species diversity there (summarized by Haffer and Prance 2001). This refuge theory was, however, contested by other authors (Colinvaux et al. 2001; Hoorn et al. 2011).

The different sub-regions of the African continent have also suffered major climate changes. During the midHolocene, much of North Africa was covered with 
grassland and scattered lakes and wetlands (Carrington et al. 2001). Low precipitation, about 14,000 years ago, led to low water levels or complete drying up of many East African lakes and seriously affected the connected wetlands (Scholz and Rosendahl 1988). This led in the following wet period to migration of some cichlid genera into the great African lakes and an astonishing speciation.

Different parts of Tropical and sub-tropical Southeast Asia have experienced large variation in the monsoons since the LGM. The hyper-arid conditions over most of South Asia after the LGM gradually changed with increased monsoon precipitation which again declined after ca. 6,500 year BP. During the late Holocene $(4,800-6,300$ years ago), the present Thar Desert was wet with high winter precipitation. From the late Holocene until about 1000 years ago, western Himalaya experienced warm and moist phases alternating with cold and dry phases. In Nepal Himalaya, an earlier warm climate turned wetter with the strengthening of summer monsoonal circulation about 9,500 years ago, but changed again to long-term aridity around 4,300 years ago (Pant 2003). Similar changes occurred in Southeast Asia with the variations in eastern Asian monsoon.

In Australia, during the LGM, rainfall was as little as $50 \%$ of present day values and many south-east Australian wetlands were dry-a time of particular stress for Australia's aquatic biota. Some deep, crater lakes persisted but there was probably a considerable diversity bottleneck. Over the last 10,000 years of the Holocene, the climate was warmer and wetter. There is recent evidence for an extended period of drying commencing as much as 600 years ago. The instrumental record shows strong variability through the period of European settlement under the influence of the multi-decadal oscillation. The recent extended drought, the driver of much recent interest in climate change in Australia, is likely a symptom of this longer term variability, although elevated global temperatures are likely to have played a major role in the regional water balance.

The impact of the predicted change of global climate on wetlands

The predictions of the Intergovernmental Panel on Climate Change [IPCC (International Panel on Climate Change) 2007] about major changes in global climate until 2100 can be summarized as follows: (1) increase in temperature affecting high latitudes more than tropical and subtropical regions; (2) changes in total precipitation and precipitation pattern; (3) a rise in sea-level of $20-60 \mathrm{~cm}$, or even more; and (4) an increase in extreme climate events. These changes will certainly induce variations in the occurrence, structure, pattern, process, and function of wetlands by modifying temperature, hydrology, biogeochemical cycles, evapotranspiration, and shifting species distribution, altering community structures and species interactions. On the other hand, changing wetlands will contribute to global climate changes through changes in carbon storage, trace gas emission, biogeochemical variation, and changes in species composition. For the major world regions treated in this volume, the situation can be summarized as follows:

In North America, any melting of the permafrost in the tundra will result in the loss of wetlands. In boreal and temperate areas, climate change will change rainfall patterns, thus affecting runoff and groundwater inflows to wetlands. In general, a decrease in precipitation or an increase in evapotranspiration will result in less-frequent flooding of existing wetlands, although the types of wetlands may not change. Greater precipitation patterns would increase the length and depth of flooding of inland wetlands. Most susceptible to these effects are depression wetlands that have very small watersheds and that are in regions between arid and mesic climates, such as the PPR of North America. These wetlands provide $50-80 \%$ of the continent's duck population and are exactly on the edge between areas to the east with abundant precipitation and arid climates to the west. Basically, any temperature increase coupled with precipitation decrease shifted the area favourable for ducks to the east. Overall, climate change would diminish the benefits of wetland conservation in the central and western PPR. Simulations further indicate that restoration of wetlands along wetter fringes of the PPR may be necessary to ameliorate potential impacts of climate change on waterfowl populations. Wetland restoration has potential to sequester $378 \mathrm{Tg}$ of organic carbon over a 10-year period in the PPR (Euliss et al. 2006). Wetlands can sequester over twice the organic carbon as no-till cropland on only about $17 \%$ of the total land area in the region.

In Europe, according to most regional climate change models, the annual mean temperatures are likely to increase more than the global mean increment. In winter, the largest warming is likely to take place in northern Europe. In summer, on the other hand, the maximum temperatures are likely to increase most in southern Europe. Annual precipitation is expected to increase in northern Europe but decrease in most of southern Europe. In northern Europe, the increased annual precipitation will be caused mainly by increased precipitation in the winter months. Nevertheless, water input from increased precipitation will be offset by the effects of increased evapotranspiration. Summer drought will probably be the most important stressful effect of changing climate on inland wetlands. The frequency and intensity of summer droughts is most likely to increase from the north to the south. Sea level rise will probably be the decisive factor 
affecting coastal wetlands especially along the Atlantic coast. The increase in extreme sea level events along the continental North Sea coast will affect costal areas of all countries from Denmark in the north to northern France in the south.

For Russia, the IPCC generally predicted a wetter and warmer climate. The projected results of an increase in annual and winter mean precipitation would be highest in boreal Asia with the result that annual runoff in the major Siberian rivers would increase significantly. Projections beyond 2010 indicated that warming would be greatest in the continental interior of Asia (Russia) and higher during winter than summer with the most pronounced warming at high latitudes. Similarly, annual precipitation would increase the most in Northern Asia (Russia) with increases in both summer and winter. Recently documented increases in Russian river discharge into the Arctic Ocean (Peterson et al. 2002, 2006) may confirm this prediction.

Warming of frozen ground can lead to ground surface subsidence and the formation of thermokarst that generate marked changes in ecosystems and landscapes. Thermokarst formation might be expected to increase the number of wetlands in Russia, but this is not necessarily true as there are other factors that influence the outcome (Smith et al. 2005).

West Siberia is warming faster than the Arctic as a whole and it also contains the world's largest stores of peat. Studies have indicated that these peatlands will release more dissolved organic carbon (DOC) leading to about a $700 \%$ increase in the DOC concentration of the rivers $(\mathrm{Ob}$ and Yenisey) draining these peatlands (Frey and Smith 2005). Increased DOC production in peatlands may have significant impacts on the optical properties of these wetlands and therefore on aquatic biogeochemical cycles and biological productivity. Changes in DOC loads to Russian wetlands may also increase thereby raising the DOC concentration in them as forested tundra becomes completely covered by forests that will move north pushing tundra to the Arctic coast.

Thaw lakes comprise $90 \%$ of the lakes and wetlands in the Russian permafrost zone and many of these are underlain by yedoma, an organic-rich Pleistocene-age loess permafrost. Warming and permafrost degradation have increased these in both number and size and, as a result, current estimates of methane production in them may be greatly underestimated (Walter et al. 2006; Smith et al. 2005).

Other impacts of climate change could include decreased inflows of glacial water in some regions and the earlier loss of ice cover together with warmer water temperatures with the predicted climate warming for Russia would result in wetland water level decreases through increased evaporation.
River deltas, such as that of the Lena, along the circumpolar arctic coast are rich in lakes and wetlands but are poorly investigated. The impact of climate change on these is not known as there are no data available for them. However, it is known that due to climate change floods have become very severe in the Lena and its tributaries (Perelet et al. 2007).

There is no consensus at the moment on what the overall direct and indirect impacts of climate change on the number of Russian wetlands will be as there is a complex interaction between land-use policies, socioeconomic conditions and the vulnerability of wetlands to climate change. Many cities and recreational, agricultural and industrial centres are located close to or within wetlands in Russia. As a result, there is a new and growing wetland issue that has emerged recently and that is human health due to zoonoses.

In China, over the past 50 years, global warming has significantly reduced the water-storage capacity. For example, the Qinghai-Tibet Plateau of High Asia has lost $13,800 \mathrm{~km}^{2}$ of wetlands and $534 \mathrm{~km}^{3}$ of water storage. In western China, $27,400 \mathrm{~km}^{2}$ of wetlands and $383 \mathrm{~km}^{3}$ of water storage have been lost. Throughout the western parts of China, the total loss of water storage is estimated to be $917 \mathrm{~km}^{3}$. As the global air temperature continues to increase, the loss of glaciers and wetlands in High Asia will continue as well but the re-distribution of precipitation in the area makes the pattern of loss difficult to predict.

For South America, the predictions of the IPCC regarding the consequences of global climate change are still rather imprecise and somewhat contradictory. Scenarios of temperature increase for the year 2100 indicate values of $1.8-5.1{ }^{\circ} \mathrm{C}$ (median $3.2^{\circ} \mathrm{C}$ ) and $1.7-3.9^{\circ} \mathrm{C}$ (median $2.5^{\circ} \mathrm{C}$ ) for northern and southern South America, respectively. Regional warming is expected to be greatest in the most continental regions, e.g., Central Amazonia. Accelerated melting of snow and ice, including glaciers in Patagonia and the Andes, will reduce water storage and discharge-buffer capacity. A rise in sea level of $20-60 \mathrm{~cm}$ is predicted, which will destroy coastal wetland areas.

Precipitation may decrease slightly near the Caribbean coast as well as over large parts of Brazil, Chile, and Patagonia, but may increase in Colombia, Ecuador, and Peru, around the equator, and in southeastern South America. However, rainfall distribution during multiannual cycles may change, with precipitation increasing during the rainy season and decreasing during the dry season. Also, an increase of extreme multiannual and short-term climate events (El Niño and La Niña, heavy rains and droughts, heat waves) is predicted.

The climate and vegetation model offered by the Hadley Center predicts the conversion of the Amazon rain forest to cerrado vegetation from 2050 to 2100 (Jenkins et al. 2005). 
Malhi et al. (2009) predict a change to a semi-deciduous forest. In both scenarios, the wetlands are not considered. They may create a dense network of evergreen riparian and floodplain forests and reduce the impact of increasing drought, when properly managed and protected.

In Africa, predictions are that temperatures will rise by $1-2.6^{\circ} \mathrm{C}$ by 2050 (Hulme et al. 2005), although the authors warn that predictions based on greenhouse gas warming have a low confidence for Africa as a result of the longterm climatic variability as well as the role of land cover changes in modifying regional climate. The quantity of precipitation received is projected to increase over the equatorial region of Africa by up to $10-20 \%$, but in the mid-latitude regions, over the deserts, it is projected to decrease by a similar or greater amount, which translates into a change in surface water availability. The Mediterranean coast of North Africa will become drier. A band running west to east, which includes parts of the Sahel and areas to the south of it, are predicted to have increasing water resources. Under a scenario of moderate climate change, severe future threats to both freshwater ecosystem functioning as well as water availability for humans may be expected, as for instance for south-western part of Africa, e.g., the Namib and Kalahari deserts,. This will be exacerbated by the accompanying changes in the frequencies and magnitudes of floods and droughts. The eastern part of South Africa, particularly east of the escarpment, will receive increased precipitation while the western coast will become drier. But, there are considerable disagreements between the predictions of different models. It is possible that the resilience of many ecosystems may be exceeded this century by an unprecedented combination of climate change and associated disturbances such as floods, drought and other global change drivers like land-use change, pollution, fragmentation of natural systems and overexploitation of resources. Another predicted effect of increasing temperature is that the distribution of tropical diseases such as malaria and bilharzia will change, potentially exposing people now living in disease-free areas to the debilitating effects of these diseases.

For tropical and sub-tropical Asia, IPCC projections predict greater rise in temperature than the mean global increase by the end of the 21st century. Also, the rise is projected to be greater in South Asia $\left(3.3^{\circ} \mathrm{C}\right)$ and Central Asia $\left(3.7^{\circ} \mathrm{C}\right)$ than in the Southeast Asia $\left(2.5^{\circ} \mathrm{C}\right)$. Also, unlike Southeast Asia, south Asia will experience warmer winters. Temperature rise will be more at higher altitudes in the Himalaya causing accelerated melting of glaciers and, consequently, the hydrological regimes of the rivers and associated wetlands will be affected. The monsoonal precipitation is projected to increase annually but exhibit increased temporal and spatial variability, with fewer rainy day and higher intensity of extreme events. Heavy rainfall events are projected to increase in western and eastern parts of south Asia. Summer precipitation is expected to decline over the semi-arid western central Asia but increase in South and Southeast Asia. Greatest concern in the region has been expressed over the sea level rise which will have severe impacts on the mangroves throughout the region.

In Australia, if greenhouse emissions are low, temperatures increases of $1-2.5{ }^{\circ} \mathrm{C}$ are likely around the year 2070, and $2.2-5.5^{\circ} \mathrm{C}$ under higher emissions. There will also be changes in temperature extremes, with fewer frosts and substantially more days over $35^{\circ} \mathrm{C}$ than currently. Under a low emission scenario in 2070, rainfall is expected to decrease by $7.5 \%$ and under a high emission scenario decrease by $10 \%$. There will be more dry days although when it does rain it is likely to be more intense. Other findings include: (1) droughts becoming more frequent, particularly in the south-west; (2) evaporation rates increasing, particularly in the north and east; (3) high-firedanger weather increasing in the south-east; (4) tropical cyclones becoming more intense; and (5) sea levels continuing to rise.

The broad, imprecise projections do not provide useful guidance on the impact of climate change on wetlands. Many of Australia's rivers and wetlands are degraded and water resources over-exploited at a time when severe drought has recently gripped large parts of the country. The projections indicate that in Australia's major watershed, the MurrayDarling Basin, conditions are likely to be slightly warmer with lower and more variable rainfall. There is a need for managing water resources including wetlands within the vagaries of a variable climate. The changing climate coupled with existing land and water uses could spell a major change in the landscapes and land uses in the basin unless clear decisions are made and options for conserving wetlands are identified and translated into on-ground outcomes. In response to the water allocation and drought conditions, an integrated management plan for the Murray-Darling Basin is being prepared (http://www.mdba.gov.au/basin_plan, accessed 24 January 2010).

The vulnerability of coastal wetlands in the Alligator Rivers Region in northern Australia to climate change and sea level rise was assessed as part of a national study. The Alligator Rivers Region contains Kakadu National Park, which has immeasurable natural and cultural value and has attracted great interest over the past 3-4 decades. It includes vast tracts of wetland on floodplains bordering its principal rivers. It was projected that a change in climate accompanied by a rise in sea level would substantively affect the physical and biological character of the wetlands on the coastal plains. Sea level rise, shoreline erosion and saltwater intrusion would change both the salt and freshwater wetlands. It is also expected that changes to the physical and biological character would have social and 
economic ramifications and affect the way in which the natural resources of the region were managed.

\section{Conclusions}

Wetlands cover about $10 \%$ of North America, $20 \%$ of South America, $10 \%$ of Russia, $7 \%$ of China, $3 \%$ of tropical and subtropical Asia, $3 \%$ of Australia, $7 \%$ of Africa, and $5 \%$ of Europe. Major benefits are (1) sponge function to store water in the landscape and to recharge the ground water table, (2) buffer function for river discharge, (3) maintenance of biodiversity, (4) water purification, (5) storage of organic carbon, (6) food production, living space and recreation for local populations and visitors.

Major threats to wetlands are (1) land reclamation for food production, (2) land reclamation for infrastructure construction, (3) water abstraction for irrigation and industrial and domestic uses, (4) disconnection from parent rivers by dike construction (river floodplains), (5) overuse of resources (peat mining, destruction of wetland forests), (6) eutrophication and pollution and (7) invasive species. Climate change may exacerbate the impacts of these threats through increases in temperature, changes in the total amount and distribution pattern of precipitation, and sealevel rise.

The global demand of arable land is steadily increasing because of a growing human population. There is increased pressure on many wetlands through the cultivation of wetland soils with increasing demand for water and land for more food production. This unilateral view neglects the multiple functions of wetlands in the landscape and for humans (Gordon et al. 2010). Considering realistic prices for water, abstraction for the production of irrigated rice in semi-arid regions is socially, economically and ecologically not sustainable and often does not compensate for environmental degradation, artificial water-shortage and increased poverty rates of local communities managing wetlands by traditional methods.

Global water requirements have increased almost tenfold during the 20th century (Biswas 1998). In the industrially developed countries of Europe and North America, the specific per capita urban water withdrawal rate is $500-8001$ days $^{-1}$; in developing agricultural countries of Asia, Africa and Latin America, the public water withdrawal is 50-100 1 days $^{-1}$ and, in individual regions with insufficient water resources, withdrawal is 10-40 1 days $^{-1}$ (Shiklomanov 1999). Jackson et al. (2001) reported that more than $1 \times 10^{9}$ people lacked access to clean drinking water. Water abstraction could rise by $18 \%$ in developed and $50 \%$ in developing countries by the year 2025 (IUCN 2000). At the same time, accessible run-off is unlikely to increase more than $5-10 \%$ by reservoir construction (Postel et al. 1996; Postel 2000). The storage and diversion of water from wetland tributaries in semiarid regions are already major threats to wetland integrity, even in protected areas. Water has already been a cause of political tension between different countries, as for instance Syria and Israel, Syria and Iraq, India and Bangladesh, USA and Mexico, and all ten riparian states of the Nile River (Wolf 1998).

The Environmental Flow Assessment (EFA) should be applied in areas of competition for water to guarantee a minimum of water that is necessary to maintain major structures and functions of connected wetlands ( $\mathrm{Nel}$ et al. 2011). EFA is defined as "how much of the original flow regime of a river should continue to flow down it and onto its floodplains in order to maintain specified, valued features of the ecosystem" (Tharme 2003).

A fundamental role of wetlands in the landscape is to buffer the run-off system. They store excess water in the rainy season and slowly release it to the ground water, streams and rivers during the dry season. This process is connected to evaporation, which affects the local and regional climate. Changing rainfall patterns will affect the surface hydrology of the major world regions modifying runoff and groundwater inflows to wetlands. In general, a decrease in precipitation, or an increase in evapo-transpiration, will result in less-frequent flooding of existing wetlands and higher fire stress, and greater precipitation will increase the length and depth of flooding of inland wetlands. Plant species distribution and community structure will be affected in both scenarios. Most susceptible to precipitation changes are depressional wetlands that have very small watersheds and that are in regions between arid and mesic climates. Low order rivers in these areas may change from a perennial to an intermittent status with negative effects on the riparian wetlands.

Because of their large catchments, large rivers and connected wetlands have a greater resilience to hydrological changes, but an increase of extreme flood and drought events may lead to increased stress to organisms and increased hydro-morphological dynamics, which will lead to an accelerated rearrangement of floodplain habitats and vegetation units. Furthermore, precipitation changes need to be considered in future water resource planning. In some developing countries, developed and under-developed sectors of the population and the economy are juxtaposed, and the more vulnerable underdeveloped sectors already have to cope with multiple stresses, of which climate variability is but one. Climate change will add an additional layer of stress, to which adaptive strategies are required.

Wetlands have important sink and source functions for climate relevant trace gases. They contribute $20-25 \%$ to the total methane emissions to the atmosphere, but they 
also sequester large amounts of carbon in their soils (Mitsch et al. 2012). Twenty to thirty percent or more of soil organic carbon is stored in wetlands and may become liberated when wetlands are lost or by inadequate management or when the climate becomes warmer and dryer. In the tundra, any melting of the permafrost may result in the loss of some, not necessarily all wetlands. The belt of permafrost soils will shift northwards releasing large quantities of $\mathrm{CO}_{2}$ and methane to the atmosphere. High latitude peat bogs certainly play a major role in the global carbon cycle by accumulating (or releasing) organic matter than tropical wetlands. Most tropical and sub-tropical wetlands show an explicit wet and dry cycle, which hinders the accumulation of organic material. Exceptions are some south-east Asian swamp forests that have accumulated large amounts of organic carbon which is now being released to the atmosphere by draining and transformation to oil palm plantations.

Wetlands harbor a considerable portion of the biodiversity of a landscape (Gopal et al. 2000, 2001). This function will become increasingly important under global climate change aspects. The Ramsar convention should be strengthened, because it requires the wise use of all wetlands, including the protection of globally important wetlands to secure habitats for migratory birds and other wildlife. But we observe an increase of exotic species because of the worldwide trade with plants and animals and an increase in genetic varieties. The detrimental impact of exotic species on the native wetland fauna and flora has been well documented. Changes in global climate will benefit exotic species by deteriorating environmental conditions for the native ones.

The temperature rise in higher latitudes will be larger and have a greater effect on the biota. In the tropics and sub-tropics, the impact of changes in total precipitation and precipitation pattern on the biota will be larger. The increase of extreme climate events may have a greater effect on the tropics and subtropics by an increased number and strength of cyclones, larger floods, and more extreme droughts and fires as a result of the increasing strength of El Nino and La Nina events, the Sahelian Climate Anomaly, of monsoons in Asia, and rainy and dry season variations in Africa, Australia and South and Central America. But the predictions of global climate models are too imprecise and the data base for regional models is often not available yet. With increasing temperature, many boreal wetlands may become forested. The impact on tropical and sub-tropical species is difficult to predict, given the lack of ecophysiological data. But most tropical and subtropical wetland species have a wide distribution range, which points to a considerable ecophysiological elasticity with respect to temperature and will likely enable them to avoid mass extinction.
Coastal wetlands are seriously threatened by the rising sea-level because they will be squeezed between advancing sea and civil constructions and dikes. They deserve specific attention because of their large biodiversity, their manifold interactions between continental ecosystems and the oceans, and their multiple services for humans.

An informed reaction of politicians would be to protect wetlands as much as possible because of their multiple benefits for humans and nature. The storage of water in the landscape by ephemeral and permanent wetlands to recharge the groundwater table, to buffer run-off and to diminish the flood amplitude of streams and rivers will be of increasing importance in the future. In near pristine wetland areas, governments should invest in measures for impact prevention of extreme floods, droughts and fire. Water level predictions are efficient tools to reduce losses in wetland agriculture, husbandry, forestry and fishery. But in densely populated areas, the increase in extreme climate events will lead to increasing flood protection measures, as shown for Europe. Conversion to cropland, reservoir construction, flood protection measures and wetland unfriendly landscape management will further reduce total wetland area and modify the flood regime in the remaining ones.

The efficiency of wetland protection will increasingly depend on catchment area management, which affects the hydrology of the tributaries and changing the total amount of water and timing of the flow regime, and the input of dissolved and solid material to wetlands. Many wetlands of global importance are connected to rivers that cross political boundaries of several countries. This will require multinational agreements for a wetland friendly watershed management and water-use policy.

The effects of global climate change will become visible only in a few decades and aggravate the problems caused by mismanagement of wetlands in the past and present (Vörösmarty et al. 2000). It remains the responsibility of respective governments to stop the destruction of their wetlands now, and protect them to successfully overcome global climate change for the benefit of their people and the environment.

\section{References}

An S, Tian Z, Yao Z, Ouyang Y, Sheng S, Wen T, Xu D, Jiang H, Cai Y, Guan B, Lei G, Wang Z, Zhou C (2012) The wetlands in Northeast Asia and High Asia: an overview. Aquat Sci (this issue)

Bayley PB, Petrere M Jr (1989) Amazon fisheries: assessment methods, current status, and management options. Can Special Publ Fish Aquat Sci 106:385-398

Béné C (2005) Contribution of inland fisheries to rural livelihoods and food security in Africa: an overview. In: Thieme ML, Abell R, Stiassny MLJ, Skelton P et al (eds) Freshwater ecoregions of 
Africa and Madagascar: a conservation assessment. Island Press, USA, pp 6-11

Biswas AK (1998) Deafness to global water crisis: causes and risks. Ambio 27:492-493

Carrington DP, Gallimore RG, Kutzbach JE (2001) Climate sensitivity to wetlands and wetland vegetation in mid-Holocene North Africa. Clim Dyn 17:151-157

Čížková H, Květ J, Comín FA, Laiho R, Pokorný J, Pithart D (2012) Actual state of European wetlands and their possible future in the context of global climate change. Aquat Sci (this issue)

Colinvaux PA, Irion G, Räsänen ME, Bush MB (2001) A paradigm to be discarded: geological and paleoecological data falsify the Haffer \& Prance refuge hypothesis of Amazonian speciation. Amazoniana 16(3/4):609-646

Costanza R, d'Arge R, de Groot R, Farber S, Grasso M, Hannon B, Limburg K, Naeem S, O’Neill RV, Paruelo J, Raskin RG, Sutton P, van den Belt M (1997) The value of the world's ecosystem services and natural capital. Nature 387:253-260

Emerton L (2005) The economic value of Africa's wetlands. In: Thieme ML, Abell R, Stiassny MLJ, Skelton P (eds) Freshwater ecoregions of Africa and Madagascar: a conservation assessment. Island Press, USA, pp 11-18

Euliss NH, Gleason RA, Olness A, McDougal RL, Murkin HR, Robarts RD, Bourbonniere RA, Warner BG (2006) North American prairie wetlands are important nonforested land-based carbon storage sites. Sci Total Environ 361:179-188

FAO (1997) Irrigation potential in Africa: a basin approach. FAO Land and Water bulletin No. 4. Rome

Finlayson CM, Davis JA, Gell PA, Kingsford RT, Parton KA (2012) The status of wetlands and the predicted effects of global climate change: the situation in Australia. Aquat Sci (this issue)

Frey KE, Smith LC (2005) Amplified carbon release from vast West Siberian peatlands by 2010. Geophys Res Lett 32:L09401. doi: 10.1029/2004GL022025

Gardner RC, Zedler J, Redmond A, Turner RE, Johnston CA, Alvarez VA, Simenstad CA, Prestegaard AJ, Mitsch WJ (2009) Compensating for wetland losses under the clean water act (Redux): evaluating the federal compensatory mitigation regulation. Stedson Law Rev 38(2):213-249

Gopal B (2012) Future of wetlands in tropical and subtropical Asia, especially in the face of climate change. Aquat Sci (this issue)

Gopal BJunk WJ, Davis JA $(2000,2001)$ Biodiversity in wetlands: assessment, function and conservation. Part 1 and 2. Backhuys Publishers, Leiden: 353 and 310p

Gopal B, Junk WJ, Finlayson CM, Breen CM (2008) Present state and future of tropical wetlands. In: Polunin N (ed) Aquatic ecosystems. Cambridge University Press, Cambridge, pp 142-154 (U.K. Foundation for Environmental Conservation)

Gordon L, Finlayson CM, Falkenmark M (2010) Managing water in agriculture to deal with trade-offs and find synergies among food production and other ecosystem services. Agric Water Manag 97:512-519

Haffer J, Prance GT (2001) Climatic forcing of evolution in Amazonia during the Cenozoic: on the refuge theory of biotic differentiation. Amazoniana 16:579-607

Hoekstra AY (2003) Virtual water: an introduction. In: Hoekstra AY (ed) Virtual water trade: Proceedings of the international expert meeting on virtual water trade. Value of Water Research Report Series No. 12, IHE Delft, The Netherlands, pp 13-23

Hoorn C, Wesselingh FP, ter Steege H, Bermudez MA, Mora A, Sevink J, Sanmartín I, Sanchez-Meseguer A, Anderson CL, Figueiredo JP, Jaramillo C, Riff D, Negri FR, Hooghiemstra H, Lundberg J, Stadler T, Särkinen T, Antonelli A (2011) Amazonia through time: Andean uplift, climate change, landscape evolution, and biodiversity. Science 330:927-931
Hulme M, Doherty R, Ngara T, New M (2005) Global warming and African climate change: a reassessment. In: Sum Low P (ed) Climate change and Africa. Cambridge University Press, New York, pp 29-40

IPCC (International Panel on Climate Change) (2007) Climate change 2007: Synthesis Report AR4. http://www.ipcc.ch/pdf/assessmentreport/ar4/syr/ar4_syr.pdf

IUCN (2000) Vision for water and nature. A world strategy for conservation and sustainable management of water resources in the 21st century. The World Conservation Union, Gland

Jackson RB, Carpenter SR, Dahm CN, McKnight DM, Naiman RJ, Postel SL, Running SW (2001) Water in a changing world. Ecol Appl 11(4):1027-1045

Jenkins G, Betts R, Collins M, Griggs D, Lowe J, Wood R (2005) Stabilizing climate to avoid dangerous climate change-a summary of relevant research at the Hadley Centre. Department for Environment Food and Rural Affairs, Met Office Hadley Centre, Exeter, UK, p 16

Junk WJ (2002) Long-term environmental trends and the future of tropical wetlands. Environ Conserv 29(4):414-435

Junk WJ (2012) Actual state of knowledge about wetlands and their future under aspects of global climate change: the situation in South America. Aquat Sci (this issue)

Junk WJ, Bayley PB, Sparks RE (1989) The flood pulse concept in river-floodplain systems. Special Publ Can J Fish Aquat Sci 106:110-127

Junk WJ, Piedade MTF, Schöngart J, Cohn-Haft M, Adeney JM, Wittmann F (2011) A classification of major naturally-occurring Amazonian lowland wetlands. Wetlands 31:623-640

Lacerda LD (ed) (2002) Mangrove ecosystems: function and management. Springer, Berlin, p 292

Loarie SR, Duffy PB, Hamilton H, Asner GP, Field CB, Ackerly DD (2009) The velocity of climate change. Nature 462:1052-1055

Malhi Y, Aragão LEC, Galbraith D, Huntingford C, Fisher R, Zelazowski P, Sitch S, McSweeney C, Meir P (2009) Exploring the likelihood and mechanisms of a climate-change-induced dieback of the Amazon rainforest. PNAS 106(49):20611-20615

Mansur MCD, Santos CP dos, Pereira D, Paz ICP, Zurita MLL, Rodriguez MTR, Nehrke MV, Bergonci PEA (2012) Moluscos limnicos invasores no Brasil: Biologia, prevenção, controleRedes Editora Ltda. Porto Alegre, p 411

MEA (Millennium Ecosystem Assessment) (2005) Ecosystems and human well-being: wetlands and water synthesis. World Resources Institute, Washington, DC

Mitchell SA (2012) The status of wetlands, threats and the predicted effect of global climate change: the situation in Sub-Saharan Africa. Aquat Sci (this issue)

Mitsch WJ, Gosselink JG (2007) Wetlands, 4th edn. Wiley, New York, p 582

Mitsch WJ, Hernandez ME (2012) Wetlands of North and Central America. Aquat Sci (this issue)

Mitsch WJ, Bernal B, Nahlik AM, Mander Ü, Zhang L, Anderson CJ, Jørgensen SE, Brix H (2012) Wetlands, carbon, and climate change. Landsc Ecol (published online)

Nel JL, Turak E, Linke S, Brown C (2011) Integration of environmental flow assessment and freshwater conservation planning: a new era in catchment management. Mar Freshw Res 62(3):290-299

NEPAD (2003) Action plan of the environment initiative of the New Partnership for Africa's Development (NEPAD). http://www.nepad. org/2005/files/documents/113.pdf (viewed July 2008)

NRC (2001) Compensating for wetland losses under the clean water act. National Research Council, National Academy Press, Washington D.C.,p 322

Pant GB (2003) Long term climate variability and change over monsoon Asia. J Indian Geophys Union 7:125-134 
Perelet R, Pegov S, Yulkin M (2007) Fighting climate change: human solidarity in a divided world. Climate change. Russia country paper. UNDP Human Development Report, Occasional Paper 2007/200, pp 1-30

Peterson BJ, Holmes RM, McClelland JW, Vorosmarty CJ, Lammers RB, Shiklomanov AI, Shiklomanov IA, Rahmstorf S (2002) Increasing river discharge to the Arctic Ocean. Science 298:2171-2173

Peterson BJ, McClelland J, Curry R, Holmes RM, Walsh JE, Aagaard K (2006) Trajectory shifts in the arctic and subarctic freshwater cycle. Science 313:1061-1066

Pittock J, Finlayson CM (2011) Australia's Murray-Darling Basin: freshwater ecosystem conservation options in an era of climate change. Mar Freshw Res 62(3):232-243

Postel SL (2000) Entering an era of water scarcity: the challenges ahead. Ecol Appl 10:941-948

Postel SL, Daily GC, Ehrlich PR (1996) Human appropriation of renewable freshwater. Science 271:785-788

Robarts RD, Zhulidov AV, Pavlov DF (2012) The state of knowledge about wetlands and their future under aspects of global climate change: The situation in Russia. Aquat Sci (this issue)

Scholz CA, Rosendahl BR (1988) Low lake stands in lakes Malawi and Tanganyika, East Africa, delineated with multifold seismic data. Science 240:1645-1648

Shiklomanov IA, (ed) (1999) World water resources: modern assessment and outlook for the 21st century. (Summary of the Monograph World Water Resources at the Beginning of the 21st
Century, prepared in the framework of IHP-UNESCO). Federal Service of Russia for Hydrometeorology and Environmental Monitoring, State Hydrological Institute, St Petersburg, Russia

Smith LC, Sheng Y, MacDonald GM, Hinzman LD (2005) Disappearing Arctic lakes. Science 308:1429-1430

Sousa PT Jr, Piedade MTF, Candotti E (2011) Letter to Nature. Nature 478:458

Tharme RE (2003) A global perspective on environmental flow assessment: emerging trends in the development and application of environmental flow methodologies for rivers. River Res Appl 19:397-441

Vörösmarty CJ, Green P, Salisbury J, Lammers RB (2000) Global water resources: vulnerability from climate change and population growth. Science 289:284-288

Walter KM, Zimov SA, Chanton JP, Verbyla D, Chapin FS III (2006) Methane bubbling from Siberian thaw lakes as a positive feedback to climate warming. Science 443:71-75

Welcomme RL (ed) (1979) Fisheries ecology of floodplain rivers. Longmann, London

Wolf AT (1998) Conflict and cooperation along international waterways. Water Policy 1:251-265

World Commission of Dams (ed) (2000) Dams and development. Earthscan Publications Ltd, London

Zak D, McInnes R, Gelbrecht J (2011) Preface: restoration biogeochemistry and ecological services of wetlands. Hydrobiologia 674:1-4 